\title{
Comment on: Prevalence of hepatitis C virus infection and the il28b genotype polymorphism
} AMONG BLOOD DONORS AND HIGH-RISK POPULATIONS

Singapore Med J 2019; 60(6): 323 https://doi.org/10.11622/smedj.2019062

Dear Sir,

We would like to comment on the article entitled 'Prevalence of hepatitis C virus infection and the IL28B genotype polymorphism among blood donors and high-risk populations'. ${ }^{(1)}$ Soh et al mentioned that "The high prevalence of the favourable IL28B CC genotype in our hepatitis C virus (HCV)-infected population suggests that the PEG-IFN+RBV combination therapy remains a viable treatment option in selected situations or individuals." ${ }^{(1)}$ In fact, the effect of IL28B genotype polymorphism on antiviral treatment for HCV is well demonstrated. The study of genotypes might help predict the response to treatment in HCV-infected cases. However, there are also other human polymorphisms that can affect the response to HCV treatment. Good examples are polymorphisms of toll-like receptors. ${ }^{(2)}$ In addition to host factor, the variant of the HCV is also observable and may relate to the response to the treatment. For example, the HCV NS3-Q80K polymorphism is strongly related to the response to EG-IFN+RBV combination therapy. ${ }^{(3)}$ A single host polymorphism study alone may not lead to a conclusive recommendation on the use of EG-IFN+RBV combination therapy. It is, therefore, necessary to consider several polymorphisms and interrelation between human and pathogen polymorphisms.

Yours sincerely,

Sora Yasri ${ }^{1}$, Viroj Wiwanitkit ${ }^{2}$

${ }^{1}$ KMT Primary Care Center, Bangkok, Thailand, ${ }^{2}$ Dr DY Patil University, Pune, India. sorayasri@outlook.co.th

\section{References}

1. Soh BYM, Kumar R, Ekstrom VSM, et al. Prevalence of hepatitis C virus infection and the IL28B genotype polymorphism among blood donors and high-risk populations. Singapore Med J 2019; 60:34-9.

2. Sghaier I, Mouelhi L, Ghazoueni E, et al. Role of TLRs and IL-6 in the outcome of chronic hepatitis C treatment in Tunisian population. Cytokine 2017; 99:297-304.

3. Ruggiero T, Proietti A, Boglione L, et al. Predominance of hepatitis C virus Q80K among NS3 baseline-resistance-associated amino acid variants in direct-antiviralagent-naïve patients with chronic hepatitis: single-centre experience. Arch Virol 2015; 160:2881-5. 